\title{
A new species of Pristiphora (Lygaeonematus) Konow, 1890 on spruce from East Siberia (Hymenoptera, Tenthredinidae)
}

\author{
With 2 figures \\ KAREL BENEŠ ${ }^{1}$ \\ ${ }^{1}$ Kreuzmannova 14, 31800 Plzeň, Czech Republik. - beneskarel@seznam.cz \\ Published on 2014-07-31
}

\section{Key words}

Pristiphora (Lygaeonematus) jacutica sp. n., taxonomy, larva, related species, lectotypes

\section{Summary}

Pristiphora (Lygaeonematus) jacutica sp. n. (female, male, larva) of the abietina-group feeding on spruce is described from Central Yakutia, East Siberia, and compared with closely related species, Pristiphora (Lygaeonematus) gerula (Konow 1904) and Pristiphora (Lygaeonematus) saxesenii (HARTIG 1837). In coloration it resembles dark specimens of $P$. (L.) gerula but shape of the penis valve is different and females are unique in having very narrow but distinct scopa as in $P$. (L.) saxesenii and also larvae are more similar to those of $P$. (L.) saxesenii. Related species are discussed and lectotypes of $P$. gerula and $P$. saxesenii are designated.

\section{Zusammenfassung}

Männchen, Weibchen und Larve der an Fichte lebende Art Pristiphora (Lygaeonematus) jacutica sp. n. aus der abietina-Gruppe werden aus Mittel-Jakutien, Ostsibirien, beschrieben und mit den eng verwandten Arten Pristiphora (Lygaeonematus) gerula (Konow 1904) und Pristiphora (Lygaeonematus) saxesenii (HaRTIG 1837) verglichen. In der Färbung ähnelt die Art dunklen Exemplaren von P. (L.) gerula. Die Form der Penisvalven ist jedoch anders und die Weibchen unterscheiden sich durch sehr schmale Schienenbürsten, ähnlich P. (L.) saxesenii. Auch die Larven ähneln denen von $P$. (L.) saxesenii. Weiterhin werden verwandte Arten diskutiert und Lectotypen von P. gerula und P. saxesenii festgelegt.

Wong (1975) defined and revised the abietina-group of Pristiphora, and divided it into three species-complexes, i.e. compressa, pallida, and wesmaeli-complex. First two complexes are associated with Picea and species of the wesmaeli-complex feed on Larix (Pinaceae). In the compressa-complex, characterized by dorsolaterally compressed abdomen and lamnium of the 1st valvula much shorter than its radix in females, fan-shaped procidentia and pale mesepisternum in males (with the exception of ezumatsuvora), three subcomplexes can be recognized: compressa s. str. and saxesenii with Eurosiberian distribution. Japanese P. ezomatsuvora and P. harai are characterized by very narrow subparallel ovipositor and black mesepisternum also in males.

While the pests of a Siberian larch (Larix sibirica LEDEBOUR), distributed from Northern Europe to Yenisei river, and Dahurian larch (Larix gmelinii (RuPR.), distributed from Siberia to the Far East are relatively well known 
(Verzhutskir 1966; 1973; Popov \& Kajmuk 2010), our knowledge of the sawflies injurinous to the Siberian spruce, Picea obovata LedeBour, has been till recently very meagre. Verzhutskij (1966) recorded Pikonema scutellata (HARTig 1837 from the Bajkal region and Togashi (1977) described P. ezomatsuvora (Togashi) from North Hokkaido (Japan), feeding on Picea jezoensis (Sieb. \& Zucc.), and Koizumi \& Togashi (1979) described its larva and biology. ZheLoKhovtsev (1988) described a new species, Nematus (Pikonema) piceae from western Siberia (Perm region) closely related to Pristiphora (Lygaeonematus) leucopodia (Hartig 1837). In 1989 Togashi described P. (L.) harai Togashi 1989 feeding on Picea glehnii MAsters, closely related to $P$. (L.) ezumatsuvora. (HARIs 2006) thought it was probably conspecific with $P$. (L.) politivaginata (TAKEUCHI 1933), but according to original description this species was associated with Larix. Although more than dozen species of spruce are known from China, only one species of Pristiphora, $P$. (L.) compressa has so far been reported to be associated with this genus (WeI, Nie \& TAeger 2006) and no spruce sawfly but four species on larch are known from Far East (LeLEJ 2012).

Our knowledge of the Siberian spruce sawflies has been substantially improved due to the paper by KAJMUK (1988) who recorded several conifer Nematinae from Siberia for the first time. She recorded eleven species associated with spruce, five of them of the abietina-group: Pristiphora (Lygaeonematus) abietina (CHRIst 1791), P. robusta (Konow 1895), previously known as a very rare species from several localities in northern and central Europe only, P. saxesenii (Hartig 1837), P. decipiens (Enslin 1916) and a new species, recorded as P. gerula, which is described below. Another species, $P$. compressa (Hartig 1837) was recorded by Popov \& Kajmuk (2010) and a list of sawflies from Yakutia, including 15 species of Nematinae feeding on spruce, was published by Popov (2011).

\section{Pristiphora (Lygaeonematus) jacutica sp. n.}

Female: Colour: Head mostly black, frons below median fovea, lower part of paraantennal field, gena (except for a blackish spot between antennal sockets and margin of gena), clypeus and labrum testaceous, narrow hind and upper orbits yellowish brown. Antennae with scape and pedicel at least dorsally black, flagellum dorsally piceous, ventrally brownish. Thorax black, pronotum light yellow with anterior margin narrowly piceous; tegulae and spots in anterolateral part of mesepisternum including prepectus testaceous; mesoscutellum laterally with small inconspicuous paler spots; legs yellow, narrow apices of coxae partly piceous, femora, fore and mid tarsi brownish yellow, distal third of hind femur and hind tarsus piceous to black. Wings subhyaline, venation brown with $\mathrm{C}, \mathrm{Al}$ and stigma brownish yellow to yellowish brown. Abdomen testaceous, apically darker, dorsally black on tergites 1 to 7 , tergites $8-10$ piceous to brownish, sheath and basis of the 2 nd valvifer black.
Head in dorsal aspect slightly but distinctly narrowed behind the eyes, genae short and rounded; postocellar area slightly convex, nearly three times as wide as long, lateral sutures flat, inconspicuous, transverse suture as a broad shallow furrow, so that lateral ocellus nearly twice its diameter from posterior side of head; coronal suture indistinct; frontal area slightly elevated, flat, ocellar basin as a shallow depression; median fovea distinct, elongate; frontoclypeal suture flat, anterior margin of clypeus subtruncate, medially clypeus scarcely as long as malar space; tentorial maculae triangular, with sharply defined sutures; anterior tentorial pit large and deep; inner orbits slightly convergent. Head covered with minute setiferous warts, slightly shining, densely pilose; vertex laterally of postocellar area and supraclypeal area nearly smooth, shining; hairs whitish to yellowish.

Antenna shorter than C + pterostigma of the forewing, about 2.5 times longer than width of the head; scape scarcely as long as apically wide, pedicel short, transverse, shorter than interantennal distance or gena; flagellomere 1 slightly curved, apically slightly oblique, subequal to flagellomere 2 and slightly shorter than maximum diameter of the eye.

Thorax with notum finely but densely coriaceously punctate, feebly shining, densely covered by short whitish hairs; notaulices posteriorly distinct, scuto-scutellar suture anteriorly angular, deep; parapsidal areas smooth, shining; mesepisternum finely punctate, with shining interspaces; epimerons and prepectus smooth; median suture of mesoscutum in posterior half indistinct; mesepisternum and mesobasisternum densely pilose, without glabrous band in the sterno-pleural line; posttergite of mesoscutellum coriaceous, less shining than scutellum.

Legs with hind femur (without trochantellus) about as long as maximum width of thorax, tarsus distinctly shorter than tibia, inner spur of hind tibia slightly longer than its apical width, reaching to about 0.5 of basitarsus, which is as long as maximum diameter of an eye, slightly longer than flagellomere 1; claws apically only slightly curved, with small and indistinct inner tooth; hind tibia both mesally and laterally with shallow but distinct longitudinal groove; segment 2 of hind tarsus distinctly longer than apical width of tibia.

Wings in distal half more, in proximal half less densely covered with short microtrichiae, C apically strongly swollen and leaving only very narrow free space of cell Sc posteriorly of M leaving Rs; pterostigma medially less than three times as wide as long, centrally thinner than on the margins, basally sclerotized nearly to rs which is obsolescent, Sc slightly before $\mathrm{M}$ joining R; nygma in cell $2 \mathrm{M}$ light brown, cell $2 \mathrm{r}-\mathrm{m}$ rather short, slightly wider than apically long. 
Abdomen posteriorly strongly compressed laterally, dorsally slightly alutaceous, ventrally finely and sparsely punctate with setiferous pits and shining interspaces; lateral flanks of tergite 9 (epipygium) smooth and shining, glabrous in basal half but with fine setiferous pits distally; hypopygium with hind margins evenly rounded laterally of ligamentum, ovipositor slightly longer than interocular distance, half as long as hind tibia, with basal plate (valvifer 2) distinctly longer than basitarsus or segment 3 of antenna; sheath (valvula 3 ) short, rectangular, only one third of the length of basitarsus, with dorsal and ventral margins subparallel, laterally nearly as long as wide, dorsally about as long as cerci, with broadly truncate apex, with very narrow scopa, (sheath directed slightly upwards so that in dorsal aspect it seems tapering to acute apex as its ventral edge is narrow); marginal setae slightly curved, directed backwards and forming an acute angle. Valvula 1 with lamnium with apical serrulae indistinct, without ctenidia as in $P$. gerula but with distal sutures less oblique. Note: in several paratypes (Fig. 1) valvula 1 malformed with radix irregularly annulate.

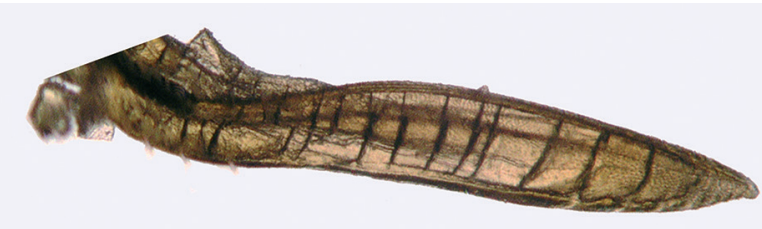

Fig. 1: P. (L.) jacutica n. sp. malformed valvula 1.

Measurements (Holotype, in mm): length -5.0; width of head -1.54 ; width of thorax -1.85 ; antenna -3.9 ; scape -0.16 ; pedicel 0.10 ; flagellomeres: $1-0.66$; $2-0.66$; $3-0.61$; $4-0.45 ; 5-0.42 ; 6-0.40 ; 7-0.42$; forewing -5.9 ; pterostigma -1.05 x 0.40; hind leg: femur -1.9 (2.0 with trochantellus; tibia -2.2 ; tarsus -1.9 ; basitarsus -0.69 ; inner hind tibial spur -0.27 ; apical width of tibia -0.23 ; interocular distance -1.00 ; eye $-0.69 \times 0.45$; interantennal distance -0.12 ; antenno-ocular distance -0.15 ; malar space -0.15 ; ovipositor -1.08 ; basal plate -0.81 ; sheath -0.27 .

Male: Colour: Head light amber yellow to testaceous dorsally, with large black spot covering postocellar area and frons anteriorly to median fovea and antennal sockets, laterally nearly to inner orbits and most of postgenae in upper part; apices of mandibles rufous. Antennae with scape and pedicel testaceous, flagellum dorsally light brown, ventrally light amber yellow, with scattered dark spiculae mesally. Thorax black on cervical sclerites, meso- and metanotum, and epimerons; mesoscutellum narrowly brownish along scuto-scutellar suture; pronotum and tegulae light amber yellow, underthorax testaceous. Legs yellowish with narrow apices of hind tibiae and tarsi piceous, apices of fore- and mid tarsi brownish yellow. Wings subhyaline with $\mathrm{C}$ and stigma testaceous, rest of venation yellowish to light brown. Abdomen dorsally black, tergites laterally, tergite 7 posterolaterally and more or less of procidentia brownish, laterotergites, sternites including hypandrium and genitalia testaceous; cerci piceous.

Head with very short rounded genae, in dorsal aspect distinctly contracted behind the eyes; postocellar area about three times as wide as long, laterally indistinctly limited, transverse suture as a shallow groove; frons slightly raised, flat, laterally and ventrally with indistinct carinae, vertex laterally of lateral ocelli distinctly concave and inner orbits slightly carinate; ocellar basin indistinct, median fovea elongate, deeper ventrally; clypeus about as long as malar space, with anterior margin subtruncate, slightly convex; POL : OOL $=1.0: 0.75$; structure as in female.

Antenna slightly longer than $\mathrm{C}+$ stigma of the forewing, more than twice as long as width of thorax; pedicel strongly transverse, flagellum slightly compressed, basal segments stout, flagellomere 1 only about three times as long as wide, shorter than maximum diameter of an eye and equal to flagellomere 2; basal flagellomeres mesally with numerous stiff dark spiculae.

Thorax with notum as in female, suturae indistinct as flat broad grooves, median suture of mesoscutum posteriorly obsolete; scuto-scutellar suture nearly rounded, posttergite not distinctly separated from scutellum, both slightly coriaceous; scutellum centrally glabrous; mesepisternum feebly and shallowly, mesobasisternum more deeply puncate, entirely pilose, prepectus and epimerons quite smooth, strongly shining. Legs with hind tarsus scarcely as long as tibia, and only scarcely longer than width of head; inner spur of hind tibia slightly longer than apical width of tibia, reaching nearly to 0.5 of basitarsus; basitarsus sbout as long as maximum diameter of an eye, about as long as flagellomere 1. Wings as in the female, Sc its own length before M, cell 2RS short, crossvein $3 \mathrm{r}-\mathrm{m}$ oblique, at least as long as anterior margin of the cell; rs absent.

Abdomen dorsally slightly transversely alutaceous, shining, ventrally feebly and shallowly punctate; procidentia broad, fan-shaped, apically slightly convex and polished, dividing tergite 8 all its length; lateral ridges rectangularly divergent; hypandrium nearly impunctate, smooth and strongly shining, as long as flagellomeres $1+2$ combined, distinctly longer than interocular distance, apically circularly rounded. Harpe apically narrowly rounded, mesally slanted, longer than distally wide; penis valve as in Fig. 2.

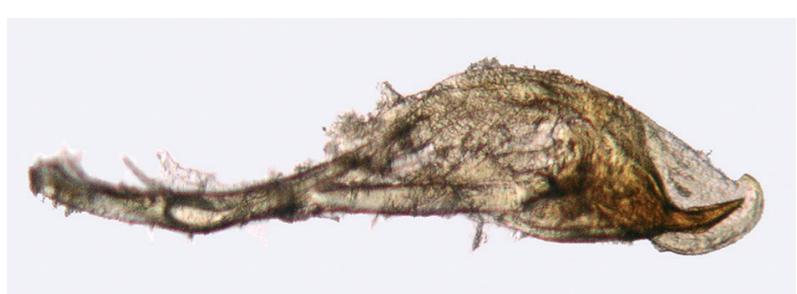

Fig. 2: P. (L.) jacutica n. sp. penis valve. 
Measurements (Allotype, in $\mathrm{mm}$ ): length -4.3 ; width of head -1.38 ; width of thorax -1.69 ; antenna -3.5 ; scape -0.16 ; pedicel -0.12 ; flagellar segments; $3-0.54$; 4-0.54; $5-0.49 ; 6-0.44 ; 7-0.40 ; 8-0.39 ; 9-0.38$; forewing -4.3 ; pterostigma $-0.9 \times 0.35$; hind leg: femur -1.23 (1.35 with trochantellus); tibia -1.46 ; tarsus -1.42 ; basitarsus -0.54 ; inner spur of tibia -0.25 ; apical width of tibia -0.23 ; interocular distance -0.96 ; eye $-0.58 \times 0.42$; interantennal distance -0.09; antenno-ocular distance -0.13; malar space -0.11 ; length of hypandrium -1.1 .

Mature larva: Width of head capsule $-1.23 \mathrm{~mm}$; total length $15-18 \mathrm{~mm}$.

Head generally as in other species of the abietina-complex, subglobose, slightly shining, yellowish brown, with brown to dark brown colour pattern in form of separated, well defined or more or less fused rounded spots, particularly on vertex strongly reticulate. Dark colour pattern consists of epicranial stripe along coronal suture reaching nearly to frontal suture where it is bifurcated towards ocularia but not reaching them. Transverse brown spot across the frons (facial stripe) is often medially constricted or divided into nearly separated spots and reaches to frontoparietal region where it is often connected with branches of the epicranial stripe. Orbital stripe is well developed and is connected, though often only feebly with epicranial stripe and reaches across vertex down to gena. Labrum and anterior tentorial depressions brown. Entire head covered with brown setae which are very scarce to nearly absent on vertex but more numerous and longer downwards, those on genae being up to $0.08 \mathrm{~mm}$ long.

Antenna four-segmented, segment 1 small, with oval flat sensilla, segments 2 and 3 ring-like, subconical, each with 2 oval flat sensillae, segment 3 and sometimes also segments 1 and 2 or 2 with one small peg-like sensilla. Apical segment bluntly conical, with 3 apical conical sensillae and several flat and small ones.

Chaetotaxy distinct: frons with 16-19 setae, 7 of which are usually located along the frontoclypeal suture; clypeus $^{1}$ with $2+2$ longer setae laterally and $2+2$ small sensillae; labrum with $2+2$ long setae laterally and about 30 placoid and campaniform sensillae, more densely in lower part, and numerous sensillae marginally; epipharynx with about 9 stout setae each side, mandible with 1 short seta lateroproximally. Maxilla: cardo with 1 short seta, palpifer with 2 curved setae ventrolaterally, 2nd segment of its palpus with 1 straight lateral seta and 3rd segment dorsoapically with 2 short blunt setae (sensillae); mesal side of palpifer and 2 basal segments of palpus with squamate surface, laterally slightly sclerotized, apical segments more sclerotized, brownish; galea dark brown, distally sclerotized with flat, apically conical sensillae.

\footnotetext{
${ }^{1}$ in saxesenii, clypeus and labrum have also 4 setae and not 6 as
} shown in Nigitz 1974, Fig. 3.
Body cylindrical, slightly shining, with slightly granulate surface. General colour greenish (?) with three longitudinal brownish grey stripes reaching to segment 9; lateral supraspiracular stripes distinctly wider than dorsal one. Thorax without dark spots, only cervical sclerites dark brown. Thoracic legs with coxae basally along the suture and adjacent parts of prehypopleurite brown infuscate; tarsi brown, distal part of femur and distal and proximal part of tibia laterally dark brown, latter with about 8 setae. Prolegs on abdominal segments 2 to 7 , anterolaterally with brownish smudge and with about 6-8 setae; segment 8 ventrally with a pair of dark setiferous warts. Abdominal segment 1 with 2 setae on both pre- and postepipleurite, those on preepipleurite on flat brownish warts; segments 2 to 8 with large dark brown elongate spots on preepipleurite and postepipleurite, postepipleurites 2 and 3 and often also preepipleurite 2 with 5-7 small separate setiferous spots; segment 9 with one small fused spot on epipleurite, 3rd abdominal segment with annulets 2 and 4 setiferous, with 4-7 short setae each side, 1st postspiracular area with 2-3 setae and 1 glanduba, 2 nd postspiracular area with 3 setae; preepipleurite with 5-6 setae and single glanduba, postepipleurite with 5-7 setae; segment 10 dorsally (suranal lobe) proximally feebly setaceous, rounded, mediodistally with a brownish elongate shade with a group of brownish to dark brown convex warts and with long dark brown setae around anus; setae on sternal side of 10 th segment on dark brown warts.

Variability: There is a certain colour variability which is most conspicuous on the thorax of females. Mesepisternum and mesobasisternum may be nearly completely testaceous to nearly entirely blackish, with only small spots in anterolateral part of mesepisternum remaining rufous (similar range of variability occurs e.g. in $P$. (L.) abietina). However, in most specimens, there is a broad pale band across mesepisternum. Some specimens are black along the frontoclypeal and /or epistomal suture; hind and upper orbits may be broadly testaceous to piceous. Antennae in male with scape and pedicel testaceous to ringed piceous as in female, flagellum dorsally piceous to yellowish brown.

The larvae show certain variability in intensity of the head colour pattern. Particularly the differences in a form of transverse facial stripe are conspicuous. In palest specimens it consists of two groups of brownish spots but in darker ones it forms a well developed transverse band reaching branches of epicranial stripe. Also spots on the pre- and postepipleurites are more or less confluent.

Anomalies: A high percentage of anomalies occur in the wing-venation: Sc in the forewing mostly distant its length from junction of $\mathrm{M}$ with $\mathrm{R}+\mathrm{M}$ but in several specimens nearly interstitial, obsolete or completely missing; cross-vein $2 \mathrm{r}-\mathrm{m}$ in the forewing often absent (1rs obsolete). Similarly high degree of individual departures from 
normal venation is reported also by ZiNovjev (1986) in his revision of the Far East species of the genus Platycampus SchiöDTE. Valvula 1 in several females with irregular segmentation of radix (see Fig. 1).

Differential diagnosis: $P$. (L.) jacutica belongs to the compressa-complex of the well defined abietina-group of Pristiphora (Wong, 1975) and can be assigned, together with $P$. (L.) saxesenii (HARTIG) and $P$. (L.) gerula (KonOw) to a distinct subgroup, characterized in females by smooth, mostly glabrous and strongly shining epipygium, sheath in dorsal aspect subacute with convergent sides and missing or obsolescent scopa, and in lateral aspect at most quadrangular, with truncate apex, its dorsal and ventral sides being subparallel. Japanese $P$. $(L$. ezomatsuvora TogAshi and $P$. (L.) harai Togashi have also shining epipygium but differ by much longer and in dorsal aspect subparallel sheath in females and entirely black underthorax in both sexes.

In colour the females resemble gerula but often they are even darker. While in gerula the mesepisternum is usually yellow, in jacutica mesobasisternum and most of mesepisternum can be piceous. From saxesenii it differs also by much darker colour - in females of saxesenii the mesepimeron is pale, at most only with sutures black, and abdomen mostly testaceous with separated black spots dorsally while in jacutica the mesepimeron is entirely black. The sheath of jacutica (in posterior aspect) possesses very narrow obsolescent scopa as in saxesenii and in dorsal aspect is tapering to narrow subtruncate apex, in gerula the scopa is absent. The saw in jacutica (lst valvula) is very similar to gerula and lacks ctenidia and apical annuli are only indistinctly separated. However, in gerula the two basal annuli are strongly oblique while in jacutica they are nearly perpendicular. In saxesenii the annuli are distinct and from the second segment on bear distinct ctenidia. The male is best separated on its penis valve.

The larva runs in the keys by Nigitz (1974) and Beneš \& KŘísteK (1979) to $P$. (L.) saxesenii with which it shares large blackish spots on preepipleurite (subspiracular lobe) and postepipleurite (surpedal lobe) of middle abdominal segments, while in other species of the compressa-complex there are small dark isolated spots. However, in jacutica the postepipleurites of abdominal segments 2 and more or less also 3 have isolated spots, not fused into large ones as on preepipleurite. From saxesenii, it can also be easily separated on different dark colour pattern of the head. Epicranial stripe reaches to frontal suture where it is bifurcate along frontal sutures but does not reach ocularia. On the other hand, orbital stripe is always connected with ocularia and often reaches to epicranial stripe, though only narrowly. In saxesenii, the bifurcation of the epicranial stripe continues along frontal sutures down to ocularia. Also thoracic legs and spots on prolegs in saxesenii are more densely blackish than in jacutica. In gerula, a simple coronal stripe reaches only to frons, transverse facial stripe is absent and both pre- and postpipleurites bear isolated dark spots. Another species with fused spots on abdominal segments, $P$. robusta, is well characterized by its size and entirely black head.

Host: Siberian spruce - Picea obovata LeDEBour.

\section{Distribution: East Siberia (Central Yakutia).}

Holotype: Female labelled: „C. Jakutia, s.(selo = village $)$ Megino-Aldan, $20 \mathrm{~km}$ nizhe ust'ja Amgi (= below the estuary of the river Amga), im.(imago) 20.v.982, Kajmuk; sad. (sadka = rearing) 02-81, l. (larva) 13.-17.vii.81, el' (= spruce) (white labels, hand-written in Russian kyrillic); Pristiphora jacutica sp. n. Beneš (white hand written label); Holotypus (red printed label)“.

Paratypes: 38 o $9,11 \sigma^{\star} o^{\star}$, the same data. Holotype deposited in the Zoological Institute, Academy of Sciences, St. Peterbourg. Paratypes also in coll. DEI Müncheberg, USNHM Washington, NSM Tokyo and NMPC Praha.

\section{Life History}

Pristiphora (Lygaeonematus) jacutica sp. n. (gerula sensu KAJMUK 1988) is according to this author a common species, the larva of which feeds on needles of spruce during June and beginning of July. Adults fly in the end of May and beginning of June. KAJMUK (l. c., p. 85) noted that the larvae from Yakutia differed from a description of those of P. gerula in fused substigmal spots and so that Yakutian population should represent a distinct subspecies.

\section{Pristiphora (Lygaeonematus) gerula (Konow 1904)}

For references to this and following species see LACOURT, 1999 and TAEgER \& BLANK, 2011.

Types: In Konow's collection in DEI, Müncheberg, there are two syntypes $\left(1+1,1 \sigma^{\star}\right)$. A male is labelled „Mecklenburg, Fr. W. Konow p. (printed), Klkh (= Kalkhorst bei Strelitz), 8.5.89 (handwriten); Coll. Konow (printed); Type (red label); Lygaeonematus gerulus Knw, Kalkh. 5.89 (written in Konow's handwritting); O. Conde det. Lygaeonematus saxeseni Htg. (printed)“. The female bears labels „Coll. Konow (printed); Type (red printed label); Pristiphora saxesenii Hartig. determ. Muche 1972 (handwritten); Lectotype; Pristiphora gerula (Konow) o , det. Beneš 1990“;. The female syntype is hereby designated as a lectotype of this specis.

Both specimens are pinned on minutia on the same kind of sheet; male in perfect condition, female with apical three segments of right antenna missing when examined in vii. 1990 . 
Differential diagnosis: Very similar to $P$. (L.) jacutica, from which it can be separated by absent scopa of the sheath and oblique basal annuli of the lamnium in the female, and shape of penis valve in the male. From saxesenii it differs by dorsally black abdomen, yellow stigma, black mesepimeron, valvula 1 without ctenidia and prominent serrulae, and obsolescent annuli in apical part. From $P$. (L.) ezumatsuvora and $P$. (L.) harai it differs by at least partly pale underthorax and much shorter sheath, and from other species of the compressa-complex it can be safely distinguished on smooth and shining epipygium and shape of sheath.

\section{Pristiphora (Lygaeonematus) saxesenii (HARTIG 1837)}

Types: In Hartig's collection in ZSM München, there are 2 우 우, $10^{\star}$ labelled Lygaeonematus saxesenii by Clément. The female labelled: „small red sheet with slant sides“; Sammlung Th. Hartig; Lygaeonematus saxeseni Htg. 우 E. Clément det.; Lectotype; Pristiphora saxesenii (Htg.) o, det. Beneš 1975 agrees well with Hartig's original description and Konow's concept of $P$. (L.) saxesenii and is hereby designated as a letotype. It was in good condition, with only right forewing nearly broken off and right hindwing damaged when studied in 1975. It is worthy of mention that sternite 6 and hypopygium overlap both lateral sides of apical tergites.

One female labelled „Type (red printed sheet, crossed out); Nematus saxesenii Th. Hartig det. (in Clément's handwriting, name printed); Sammlung Th. Hartig (printed); saxeseni n. (old Hartig's ornamental sheet with ventral side up); Pteronea (sic!) leucotrocha Htg. Conde det. (in Conde's handwriting) " actually belongs to Nematus leucotrochus HarTig 1837. As it is probable that Hartig wrongly labelled this specimen „saxeseni n.“, as it does not correspond with Hartig's original decription of saxesenii, Conde correctly identified it and probably stroke out the word „Type“. A single male could not be dissected and therefore has not been designated as paralectotype.

Differential diagnosis: From other species of the group it is characterized by pale mesepimeron and, with the exception of $P$. (L.) gerula and $P$. (L.) jacutica by smooth and shining epipygium and shape of the sheath. Females can be separated from $P$. (L.) gerula and $P$. (L.) jacutica on distinct serrulae and ctenidia of valvula 1 , entirely pale mesepimeron and mostly pale abdomen with a row of median dark spots. Males are best characterized by the shape of penis valve.

Variability: Mesonotum of the female can be entirely black or with testaceous part of mesoscutum, on scutellum and around it; mesepimeron entirely pale or with sutures darkened, in darkest specimens also dorsal part of mesepisternum adjacent to epimeron brown; abdomen dorsally mostly pale with only small blackish median spots on tergites or mostly blackish with only lateral and narrow posterior margins pale. For differential diagnosis see comparison with gerula under this species.

\section{Pristiphora (Lygaeonematus) robusta Konow 1895}

Konow (1895) described this species from a single female, without any other data except that it comes from Bohemia. The only other specimen from Central Europe was found in Hradec Králové, i.e. in the lowland region of Eastern Bohemia, beyond area of natural distribution of its host plant with only scarce spruce plantations. The only other records of this species are known mostly from the northern tajga belt only with natural stands of spruce and based on specimens reared from larvae living gregariously on spruce. However, the mention by Nigitz (1974) who regarded Enslin's data on its distribution in Bohemia as doubtful and noted that this species is restricted to the Northern Europe only, is probably based on overlooking the type locality given by Konow. Forsius (1911) shortly described a male, larva and life history. Though the species is structurally very closely related to other species of the compressa-complex of the abietina-group, it was mentioned neither by LINDQvist (1968) nor by Wong (1975) in their revisions of this group. From other species of the abietina-group, $P$. (L.) robusta can be safely separated on its size $(9-11 \mathrm{~mm}$ in female, $7.5-8.5 \mathrm{~mm}$ in male), mostly black colour, posterolaterally nearly straight hypopygium and whitish proximal part of hind tibia in female, in male by entirely reddish yellow antennae, mesobasisternum, legs and sternites. Also the genital characters are distinct: female sawsheath is in dorsal aspect distinctly wider than in $P$. (L.) compressa, penis valve in male with long and narrow, slightly curved valvispina.

Larva (described by Fonsius 1911: 83): Length 18-22 mm, body green, head brownish black; thoracic legs mostly black; body with three longitudinal dark stripes, the dorsal one is half as wide as lateral ones; two black spots above each proleg, anterior one located more dorsally; segment 9 with one, apical segment without black spot. Pupation in moss. From other species of the abietina-group it can be separated on its entirely blackish head and size.

\section{Host: Picea abies Karst., P. obovata Ledeb.}

Distribution: Eurosiberian species widely but scarcely distributed throughout northern Eurosiberia in the tajga-belt but recorded also from Central Europe. Czech Republic (KonOw 1895; Gregor \& BAŤA 1942; HolušA \& Roller 2000), Slovakia (Roller 1999), Finland (Forsius 1911; Hellén 1975), Sweden (Conde 1940, Olofsson 1989), Estonia (HeidemaA 2006), N.W. Russia (Hellén 1975), Eastern Siberia (Yakutia, approx. $62^{\circ} \mathrm{N}$, $129^{\circ} \mathrm{E}$, KAJMUK, 1988). 
Material examined $\left(7 \circ \circ\right.$ ㅇ $\left.5 \sigma^{\top} \sigma^{\top}\right)$ : Holotype (studied in vii.1990 through the courtesy of Dr. A. Taeger): $q$ labelled: „Lygaeonematus robustus Knw. Bohem. (handwritten); Coll. Konow (printed); Type; Holotypus (red printed label). Slide labelled: Prep. Symphyta No. 172, Conde 1940; Lygaeonematus robustus Knw, क Type, säge, Bohem; 3897 GBIF-GISHym“; Deposited in SDEI, Müncheberg. GBIF 3897. In good condition but abdomen dorsally gnawed (by dermestids?) and right hind tibia missing (see photo in TAEgER \& BlANK (2011).

Bohemia or., Hradec Králové, 1 + sine data, lgt. Uzel, coll. NMPC; Sweden, Lapland, Station Kåbdalis $\left(66^{\circ} 15 \mathrm{~N}^{\prime}\right.$, $\left.20^{\circ} \mathrm{E}\right) 2$ 우 $ᄋ, 2 \sigma^{\top} \sigma^{\top}$ ex larvae in colony on Picea exc., 28.vii.1939, ecl. in lab. ii.-iii.1940, lgt. O. Conde (handwritten), coll. ZMHUB; ditto o $0^{\star}$ labelled: Suec. Station Kåbdalis, larva 28.vii.1939 on Picea exc. in colony, ecl. ii.-iii.1940, No: 1; O. Conde; Pristiphora robusta Knw. conf. c. Type, Conde 1940, (male „im Leben rotgelb“), coll. SDEI; Russia, East Siberia, Yakutia, river Lena, village Edey, $200 \mathrm{~km}$ SW of Yakutsk, 우 ${ }^{\star}$ Yanulska and Kaimuk, larva 12.vii.1980, cocoon 13.-22.vii.80, imago 13. and 6.iv.1981, coll. NMPC; ditto, o o Kharyyalakh island, Lena river and Pokrovsk $\left(62^{\circ} \mathrm{N}, 129^{\circ} \mathrm{E}\right)$ lgt. Kaimuk, coll. ZMP.

Variability: There are only slight structural and colour variations: frontal wall can be slightly but broadly notched, colour of female can be nearly entirely black, only with labrum pale, abdomen ventrally dark brown with pale median stripe, apex of $\mathrm{C}$ and $\mathrm{R}$ light brown, pterostigma light to dark brown, blackish centrally, middle and hind femur mostly black, tegula blackish brown. No differences were found between populations from Sweden and Yakutia except for slightly darker color of the Siberian specimens.

\section{Acknowledgements}

My thanks are due to the former and present custodians of the collections for kind loans of specimens under their care. They are (in alphabetical order): Dr. E. Diller (Zoologische Sammlung des Bayerischen States, München, coll. Enslin and Hartig), †Dr. M. Fischer (Naturhistorisches Museum, Wien), †Dr. E. Königsmann, (Zoologisches Museum der Humboldt Universität zu Berlin), †Prof. Dr. T. Kontuniemi and $\dagger$ Mr. E. Lindqvist (Helsinki), Dr. J. Macek (National Museum, Praha), Dr. J. Oehlke and Dr. A. Taeger, (SDEI, formerly Eberswalde, now Müncheberg), Mr. J. Quinlan (British Museum of Natural History, London), Dr. J. Stehlik (Moravian Museum, Brno), Dr. V. I. Tobias and Dr. A. N. Zinovjev (Zoological Institute, Academy of Sciences, St. Petersburg). Prof. Ing. J. Křístek (formerly Agricultural University, Brno) and $\dagger$ Assoc. Prof. Vl. Martinek (formerly Research Institute of Forest Management and Game Protection, Zbraslav-Strnady) allowed me to study numerous reared specimens. Prof. Dr. I. Togashi (Ishikawa pref., Japan) kindly presented me with the paratype of P. ezomatsuvora and to Dr. J. Macek, NMPC) I am grateful for photos.

\section{References}

Beneš, K. \& KŘísteK, J. 1976: A new species of the genus Pristiphora (Hymenoptera, Tenthredinidae) feeding on Norway spruce. - Acta Entomologica Bohemoslovaca, Praha 73 (6): 404-415.

Beneš, K. \& KŘísteK, J. 1979: Present state of taxonomic knowledge of European species of the families Pamphiliidae, Diprionidae and Tenthredinidae feeding on spruce (Hymenoptera, Symphyta). - Acta Universitatis Agriculturae, Facultas Silviculturae, Brno, C 48: 77-118. (In Czech, Russian and German summary).

Conde O. 1940: Die Nematinen der Paläarktis unter teilweiser Berücksichtigung der Nearktis: 244 pp., 443 figs. - Unpublished manuscript deposited in Zoologisches Museum, Berlin. Ex ECatSym.

Forsius, R. 1911: Zur Kenntnis einiger Blattwespen und Blattwespenlarven. - Meddelanden af Societas pro Fauna et Flora Fennica, Helsingfors 37 (1910-1911): 77-88, 222.

Gregor, F. \& BAŤA, L. 1942: Podřád Symphyta (Chalastogastra, Tenthredinidae). - In: Prodromus Hymenopterorum patriae nostrae, Pars V. - Sborník entomologického oddělení Zemského Musea v Praze 20 (250): 259-344. (In Czech).

HARIS, A. 2006: Study on the Palaearctic Pristiphora species (Hymenoptera: Tenthredinidae). - Natura Somogyiensis, Kaposvár 9: 201-277.

HeidemaA, M. 2006: Additions and Changes to the Checklist of Sawflies (Hymenoptera: Symphyta) of Estonia. (1): 341-342. - In: Blank, S. M.; Schmidt, S. \& Taeger, A. (eds.): Recent Sawfly Research: Synthesis and Prospects. - Goecke \& Evers, Keltern: $704 \mathrm{pp}$.

Hellén, W. 1975: Die Nematinen Finnlands IV (Hymenoptera, Tenthredinidae) Gattung Pristiphora Latreille. - Notulae Entomologicae, Helsingfors 55: 97-128.

HolušA, J. \& Roller, L. 2000: The records of rarely collected sawflies of the genus Pristiphora subg. Lygaeonematus (Hymenoptera, Tenthredinidae) in the Czech Republic. - Acta Universitatis Agriculturae et silviculturae Mendelianae brunensis 48 (5): 7-11.

KAIMUK, E. L. 1988: Conifer sawflies of the subfamily Nematinae of Central Yakutia. - In: Insects of the deciduous and taiga biocenoses of Yakutia: pp. 61-87. Yakutsk, 1988. (In Russian).

Koizumi, C. \& Togashi, I. 1979: The life history of Pristiphora ezomatsuvora TogAshi (Hymenoptera, Tenthredinidae) with description of larva pest to Picea species. - Journal of the Japanese Forestry Society, Tokyo 61 (3): 105-106. 
Konow, F. W. 1895: Neue oder wenig bekannte Tenthrediniden und eine analytischen Übersicht der Gattung Holcocneme KNw. - Termászetrajzi füzetek, Budapest 18: 50-57.

Konow, F. W. 1904: Revision der Nematiden Gattung Lygaeonematus KNw., (Hym.). - Zeitschrift für systematische Hymenopterologie und Dipterologie, Teschendorf in Mecklenburg 4 (4): 193-208.

KřísteK, J. 1973: Bestimmung erwachsener Afterraupen der sog. saxeseni-Gruppe (Tenthredinidae, Hymenoptera). - Acta Universitatis Agriculturae, Facultas silviculturae, Brno, C 42: 207-210.

LAcourt, J. 1999: Répertoire des Tentredinidae ouestpalearctiques (Hymenoptera, Symphyta). Mémoires de la SEF, Paris 3: 1-432

LeleJ, A. S. (ed.) 2012: Annotated Catalogue of the Insects of Russian Far East. Vladivostok, Dal'Nauka 1: 1-636. (In Russian)

Nigitz, H. P. 1974: Über die Fichten-Nematinen (Hym., Tenthredinidae) der Steiermark. - Zeitschrift für angewandte Entomologie, Berlin 75: 264-284.

OlofsSON, E. 1998: Två för Swerige nya växtsteklar med kolonilevade larver på gran. - Entomologisk Tidskrift, Stockholm 110 (1-2): 43-45.

Popov, A. A. \& Kajmuk, E. L. 2010: The sawflies of the family Tenthredinidae (Hymenoptera: Symphyta) of Yakutia. - Proceedings of the Russian Entomological Society, St. Petersburg 81 (2): 67-73. (In Russian).

Popov, A. A. 2011: Synopsis of dendro-tamnobiotic sawflies of the family Tenthredinidae (Hymenoptera, Symphyta) of Yakutia. - Proceedings of the Russian Entomogical Society, St. Petersburg 82: 77-88. (In Russian).

Roller, L. 1999: Check-list of sawflies (Hymenoptera, Symphyta) of Slovakia. - Entomological Problems, Bratislava 30 (2): 17-48.

TAeger, A. \& Blank, S. M. 2011: ECatSym - Electronic World Catalog of Symphyta (Insecta, Hymenoptera). - Program version 3.9, Data version 38 (07.12.2011). Digital Entomological Information, Müncheberg. http://www.zalf.de.home_zalf/institute/dei/php_ ecatsym/ecatsym.php.

TAKeuchI, K. 1933: Undescribed sawflies from Japan. Transactions of the Kansai Entomological Society 4 : 17-34.
Togashi, I. 1977: Description of New Sawfly, Pristiphora ezomatsuvora (Hymenoptera, Tenthredinidae) Injurious to Picea glehnii in Japan. - Applied Entomology and Zoology, Tokyo 12 (1): 1-13.

Togashi, I. 1989: A new sawfly, Pristiphora harai (Hymenoptera: Tenthredinidae) collected from red spruce, Picea glehnii Masters, in Japan. - The Canadian Entomologist, Ottawa 121 (7): 619-622.

TogAshi, I. 1997: Symphyta (Hymenoptera) collected by Dr. Y. Nishijima in Hokkaido, Japan. - Bulletin of the Biogeographical Society of Japan, Tokyo 52 (1): 1-6.

Verzhutskij, B. N. 1966: Sawflies of the Baikal region. Nauka, Moskva: 164 pp. (In Russian).

Verzhutskij, B. N. 1983: Phytophagous insects in the ecosystems of East Siberia. - Nauka, Novosibirsk: 302 pp. (In Russian).

Wei, M.; Nie, H. \& Taeger, A. 2006: Sawflies (Hymenoptera: Symphyta) of China - Checklist and Review of Research: 505-574. - In: Blank, S. M.; SCHMidT, S. \& TAeger, A. (eds.): Recent Sawfly Rersearch: Synthesis and Prospects. - Goecke \& Evers, Keltern: $704 \mathrm{pp}$.

Wong, H. R. 1975: The abietina-group of Pristiphora (Hymenoptera: Tenthredinidae). - The Canadian Entomologist, Ottawa 107: 451-463.

Zhelokhovtsev, A. N. 1988: Hymenoptera Symphyta. In: Zhelokhovtsev, A. N.; Tobias, V. I. \& Kozlov, M. A.: Hymenoptera, 6. - Keys to Identification of Insects of the European part of the USSR, 3 (No 158). - Nauka, Leningrad: 268 pp. (In Russian).

Zhelokhovtsev, A. N. \& Zinovjev, A. G. 1995: A list of the sawflies and horntails (Hymenoptera, Symphyta) of Russia and adjacent territories. Entomologicheskoe Obozrenie 74 (2): 395-415. (In Russian).

Zinovjev, A. G. 1986: Sawflies of the genus Platycampus SchiöDte (Hymenoptera, Tenthredinidae) of the Soviet Far East. - In: Hymenoptera of East Siberia and Far East. - Acad. Sci. USSR. Far East Science Centre, Vladivostok: pp. 3-14. (In Russian). 